\title{
Occurrence and crystal chemical features of protoferro- anthophyllite and protomangano-ferro-anthophyllite from Cheyenne Canyon and Cheyenne Mountain, U.S.A. and Hirukawa-mura, Suisho-yama, and Yokone-yama, Japan
}

\author{
Shigeho SUENO*†, Shigeru MATSUURA**, Michiaki BUNNO*** \\ and Masanori KUROSAWA* \\ *Institute of Geoscience, University of Tsukuba, Tsukuba, Ibaraki 305-8571, Japan \\ **Central Research and Development Center, Taiheiyo Cement Corporation, Sakurashi, \\ Chiba 285-8655, Japan \\ ***Geological Museum, Geological Survey of Japan, AIST, 1-1-1 Higashi, Tsukuba, \\ Ibaraki 305-8567, Japan
}

\begin{abstract}
The crystal chemical features and occurrence of the new orthoamphiboles (space group Pnmn), protoferro-anthophyllite and protomangano-ferro-anthophyllite, are described. Protoferro-anthophyllites (PFA) are found in fayalite masses from granitic pegmatites at Cheyenne Canyon and Cheyenne Mountain, Colorado, U.S.A. and at Hirukawa-mura, Gifu Prefecture, Japan. Protomangano-ferro-anthophyllites (PMFA) are found in Mn-rich fayalite masses from granitic pegmatites at Suisho-yama, Fukushima Prefecture, and in bedded manganese ore deposits at Yokone-yama, Tochigi Prefecture, Japan. The empirical formulas of PFA from Hirukawa-mura and PMFA from Yokone-yama are $\left(\mathrm{Fe}_{1.54} \mathrm{Mn}_{0.42} \mathrm{Mg}_{0.14}\right) \mathrm{Fe}_{5}\left(\mathrm{Si}_{7.9} \mathrm{Al}_{0.1}\right) \mathrm{O}_{22}(\mathrm{OH})_{2}$ and $\left(\mathrm{Mn}_{1.38} \mathrm{Fe}_{0.59}\right)\left(\mathrm{Fe}_{4.1} \mathrm{Mg}_{0.9} \mathrm{Ca}_{0.03}\right) \mathrm{Si}_{8} \mathrm{O}_{22}(\mathrm{OH})_{2}$, respectively. The unit cell parameters of PFA are $a=9.388(2), b=$ 18.387(4), and $c=5.347(1) \AA$, and those of PMFA are $a=9.425(2), b=18.303(4)$, and $c=5.345(1) \AA$. These minerals are isostructural with synthetic protofluorian-lithian-anthophyllite (Pnmn, $Z=2)$, and have a straight double-tetrahedral chain (O(5)-O(6)-O(5) angle of 177 and 179 , respectively) and $\mathrm{M}(1), \mathrm{M}(2)$, and $\mathrm{M}(3)$ octahedra of regular shape. PFA and PMFA are optically biaxial negative with refractive indices $\alpha=1.690, \beta=$ 1.710 , and $\gamma=1.726$, and $\alpha=1.695, \beta=1.714$, and $\gamma=1.731$, respectively. The density (calc.) of PFA is 3.54 and that of PMFA is $3.44 \mathrm{~g} / \mathrm{cm}^{3}$. Some PFA and PMFA include fine clinoamphibole lamellae (space group $C 2 / m)$. PFA may be produced by hydrothermal alteration of fayalite, and PMFA may be similarly produced by alteration of $\mathrm{Mn}$-rich fayalite and also by metasomatism in bedded manganese ore deposits.
\end{abstract}

\section{Introduction}

Amphiboles are one of the most important rock-forming minerals. Many mineralogical, petrologic and crystallographic studies of amphiboles have been carried out, and their important results are summarized in several reviews and textbooks (e.g., Hawthorne, 1981; Deer et al., 1997). The basic structural unit of an amphibole can be represented by the tetrahedral-octahedral-tetrahedral stacking unit (T-O-T unit). Because of the existence of different possible octahedral stacking sequences of this unit, several amphibole polymorphs can be generated (Fig. 1). Whether the apices of the octahedra point is in the $+a$ or $-a$ direction (for

†Deceased March 11, 2001

M.Kurosawa, kurosawa@arsia.geo.tsukuba.ac.jp Corresponding auther

S. Matsuura, shigeru_matsuura@taiheiyo-cement.co.jp

M. Bunno,m.bunno@aist.go.jp example), different amphibole polymorphs can be generated (Fig. 1). It has long been believed that natural amphiboles have only two possible stacking sequences, $(++++)$ or (---) for clinoamphiboles and (++--) for orthoamphiboles, although Gibbs et al. (1960) and Gibbs (1969) reported a synthetic $(\mathrm{Mg}, \mathrm{Li})$ amphibole with (+-+-) stacking, which they termed a "protoamphibole" (Fig. 1).

Recently, Matsuura and Sueno (1984) and Matsuura et al. (1985) found two new ferro and ferro-manganese amphiboles from granitic pegmatites and manganese ore deposits. Chemically and optically, these amphiboles resembled grunerite and/or ferro-anthophyllite, but they had a protoamphibole structure (Sueno et al., 1998). These new amphiboles, therefore, were the first minerals among the natural biopyribole species with a proto-type stacking sequence (+-+-). The crystal structures and polyhedral distortions estimated from electron density distributions have already been reported 
(a)
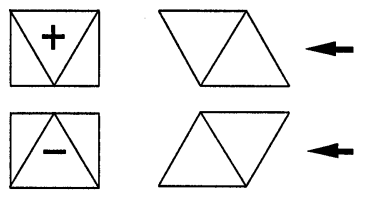

(b)

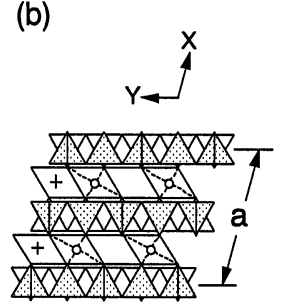

$\mathrm{C} 2 / \mathrm{m}$

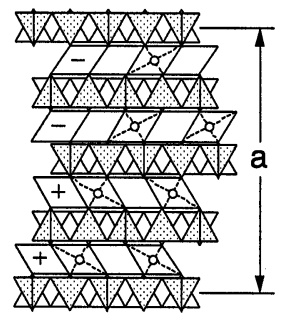

Pnma

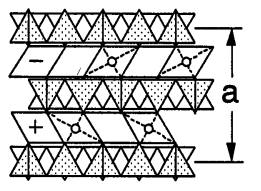

Pnmn

Figure 1. (a) Definitions of "+" and "-" orientations of the octahedra in amphiboles. When the orientation is viewed along the direction of the arrow (the $c$ axis), the triangular face of the octahedron facing the viewer may point either up (the + orientation) or down (the - orientation). The two front views are shown on the left. (b) Schematic representation of the layer-stacking sequences projected down $\mathrm{Y}$ of various amphibole structure types (modified from Hawthorne (1981)). Different amphibole polymorphs are generated by different octahedral stacking sequences of the unit, which can be defined by whether the apices of the octahedra have the + or - orientation. Stacking sequences are $(++++)$ or $(---)$ for the $C 2 / m$ structure type, (++--) for the Pnma structure type, and (+-+-) for the Pnmn structure type (protoamphiboles).

(Sueno et al., 1998); their occurrence, however, has not yet been described. Detailed information on their occurrence is important for the examination of the stability fields and for finding other protobiopyriboles. For this reason, we here report the occurrence of natural protoamphiboles from Hirukawa-mura, Suisho-yama, and Yokone-yama, Japan, and from the Cheyenne Canyon and Cheyenne Mountain of Colorado, U. S. A. Their physical properties and crystal structures are also summarized.

\section{Occurrence and chemical properties of protoamphiboles}

The two natural protoamphiboles have been named protoferro-anthophyllite and protomangano-ferroanthophyllite, respectively (Sueno et al., 1998), and the names have been approved by the Commission on New Minerals and Mineral Names of the International Mineralogical Association. For sake of brevity, protoferro-anthophyllite and protomangano-ferro -anthophyllite are referred to in this paper by the acronyms PFA and PMFA, respectively.

PFA was found in fayalite-laihunite-magnetitequartz massive aggregate from granitic pegmatites in the Cheyenne Canyon and Cheyenne Mountain area of Colorado, and at Hirukawa-mura, Japan (Table 1). PMFA was found in a Mn-rich fayalite or laihunite massive block from granitic pegmatite at Suisho-yama, Japan, and also in the metamorphosed bedded manganese ore deposit at Yokone-yama, Japan (Table 1).

Some of these protoamphiboles included submicroscopic intergrowths or lamellae of the clinoamphibole (space group $C 2 / m$ ) grunerite, estimated from the cell parameters, observed in single-crystal precession photographs. The protoamphiboles were intergrown with the clinoamphibole with orientation $a_{\mathrm{pa}} / / a_{\mathrm{ca}}^{*}, b_{\mathrm{pa}} / / b_{\mathrm{ca}}$, and $c_{\mathrm{pa}} / / c_{\mathrm{ca}}$ (pa $=$ protoamphibole, $\mathrm{ca}=$ clinoamphibole). The modal (composition) proportion of the two amphiboles varied from specimen to specimen.

Major element compositions of the protoamphiboles were reported by Sueno et al. (1998). PFA contained predominant Fe and a small amount of Mn, and PMFA contained $\mathrm{Mn}, \mathrm{Fe}$, and a relatively large amount of $\mathrm{Mg}$. Contents of $\mathrm{Al}$ and $\mathrm{Ca}$ were trace in both minerals. Since reasonable mole ratios for total cations and $\mathrm{Si}$

Table 1. Sample locations of protoferro-anthophy llit e and protomangano-ferro-anthophyllite

\begin{tabular}{llll}
\hline \multicolumn{1}{c}{ Sample } & \multicolumn{1}{c}{ Locality } & Occurrence & Registration No.*1 \\
\hline Protoferro-anthophyllite & Cheyenne Canyon, El Paso Co., Colorado, U.S.A. & pegmatite & AMNH 10928*2 \\
Protoferro-anthophyllite & Cheyenne Mountain, El Paso Co., Colorado, U.S.A. & pegmatite & USNM R3516*2 \\
Protoferro-anthophyllite & Hirukawa-mura, Gifu Pref., Japan & pegmatite & UMUT 25130*3 \\
Protoferro-anthophyllite & Hirukawa-mura, Gifu Pref., Japan & pegmatite & UMUT 25136 \\
Protoferro-anthophyllite & Hirukawa-mura, Gifu Pref., Japan & pegmatite & UMUT 25137 \\
Protomangano-ferro-anthophyllite & Suisho-yama, Kawamata, Fukushima Pref., Japan & pegmatite & UMUT 25132 \\
Protomangano-ferro-anthophyllite & Suisho-yama, Kawamata, Fukushima Pref., Japan & pegmatite & UMUT 25133 \\
Protomangano-ferro-anthophyllite & Suisho-yama, Kawamata, Fukushima Pref., Japan & pegmatite & UMUT 25134 \\
Protomangano-ferro-anthophyllite & Yokone-yama, Awano, Tochigi Pref., Japan & Mn deposit & UMUT 25129 \\
Protomangano-ferro-anthophyllite & Yokone-yama, Awano, Tochigi Pref., Japan & Mn deposit & UMUT 25135 \\
\hline
\end{tabular}

${ }^{* 1}$ AMNH, American Museum of Natural History Collection; USNM, U.S. National Museum Collections; UMUT, University Museum Collection of the University of Tokyo. ${ }^{* 2}$ Samples were originally labeled as fayalite but contained protoferro-anthophyllite (Sueno and Matsuura, 1986). ${ }^{* 3} \mathrm{All}$ UMUT samples were registered as protoferro-anthophyllit e or protomangano-ferro-anthophyllite. 
were obtained from the electron microprobe analysis data in which $\mathrm{Fe}$ content was calculated as $\mathrm{FeO}$, almost all of iron in the protoamphiboles was considered to be $\mathrm{Fe}^{2+}$ (Matsuura, 1984). No $\mathrm{Li}$ or $\mathrm{F}$ content in the protoamphiboles from the granitic pegmatites were detected with the semi-quantitative ion microprobe analyses (Matsuura, 1984).

\section{Protoferro-anthophyllite}

\section{Cheyenne Canyon and Cheyenne Mountain specimens}

The Cheyenne Canyon specimen is a part of the American Museum of Natural History Collection (Table 1) and was originally registered as fayalite. The specimen was collected probably from a vug in granite or pegmatite in the Cheyenne Canyon area, El Paso County, Colorado (Sueno et al., 1985). The Cheyenne Mountain specimen is a part of the U.S. National Museum Collection (Table 1) and was also originally registered as fayalite. The specimen could have been collected from a vug in granite or pegmatite on Cheyenne Mountain, or from pegmatite at Stove Mountain or St. Peters Dome, El Paso County (Sueno et al., 1985). The Cheyenne Canyon, Cheyenne Mountain, Stove Mountain, and St. Peters Dome areas are located on the rim of the Pikes Peak batholith. The batholith is a Proterozoic (1.3-Ga) composite intrusive body composed of gabbro, monzonite, syenite, riebeckite granite, fayalite granite, and biotite granite (Barker et al., 1975). Many pegmatites and aplites occur in these granites (Barker et al., 1975).

The Cheyenne Canyon and Cheyenne Mountain specimens are black or dark brownish massive blocks and consist mainly of fayalite and laihunite, which are associated with small amounts of magnetite, PFA, annite, and quartz (Sueno et al., 1985). The fayalite was transparent, but the laihunite was opaque under the microscope with a grayish color and weak double reflection in reflected light.

The PFAs in both specimens are brownish yellow, transparent, acicular crystals less than $3 \mathrm{~mm}$ long. The amphiboles resemble grunerite under the microscope but are easily distinguishable because of their parallel extinction, except for the polycrystalline aggregates and the twined crystals. The protoamphiboles from Cheyenne Mountain are almost completely intergrown with the clinoamphiboles $(\gamma \wedge \mathrm{c}$ $=8-18^{\circ}$ ) under the microscope. The protoamphiboles without optical intergrowths also include more than $50 \%$ by volume of clinoamphiboles, judged from the intensities of the reflections in the single-crystal precession photograph. Diffraction spots of the clinoamphibole phase did not vanish by heating in air even at $850 \mathrm{C}(3 \mathrm{~h})$ (Matsuura, 1984). On the other hand, no clinoamphibole intergrowths are observed in the single crystal precession photographs of compositions of both PFAs are almost identical (Sueno et al., 1998), and the empirical formula is $\left(\mathrm{Fe}_{1.65} \mathrm{Mn}_{0.35}\right) \mathrm{Fe}_{5} \mathrm{Si}_{8} \mathrm{O}_{22}$ $(\mathrm{OH})_{2}$ on the basis of $\mathrm{O}=23$ (anhydrous) for a unit cell.

\section{Hirukawa-mura specimens}

The Hirukawa-mura specimens were collected from pegmatites at Tsuge Quarry and the other granite quarries in Tahara, Hirukawa-mura, Gifu Prefecture, Japan. The Hirukawa-mura area is underlain by the Naegi granite, in which many granitic pegmatites with miarolitic cavities occur (Shibata, 1939; 1952). The miarolitic cavities include mainly quartz, albite, microcline, muscovite, biotite, zinnwaldite, fayalite, schorl, beryl, topaz, fluorite, zircon, xenotime, cassiterite, chabazite, and stilbite (Shibata, 1939).

The present specimens are nodule-like dark brown single fayalite crystals, about $5 \mathrm{~cm}$ in diameter, and they are enclosed in coarse euhedral microcline (perthite) from the pegmatite vein. The fayalite masses are surrounded by minute flakes of annite and coarse-grained smoky quartz.

The PFA is included in the fayalite mass as brownish yellow acicular crystals less than $3 \mathrm{~mm}$ long. It is associated with laihunite, annite, magnetite, and quartz, and often forms radial aggregates covering euhedral magnetite (Fig. 2). The crystal from Hirukawa-mura is almost a single phase of PFA without intergrowths of clinoamphibole. The empirical formula is $\left(\mathrm{Fe}_{1.54} \mathrm{Mn}_{0.42} \mathrm{Mg}_{0.14}\right) \mathrm{Fe}_{5}\left(\mathrm{Si}_{7.9} \mathrm{Al}_{0.1}\right) \mathrm{O}_{22}(\mathrm{OH})_{2}$. The specimens are deposited at the University Museum collection of the University of Tokyo (Registration Nos. 25130, 25136, and 25137).

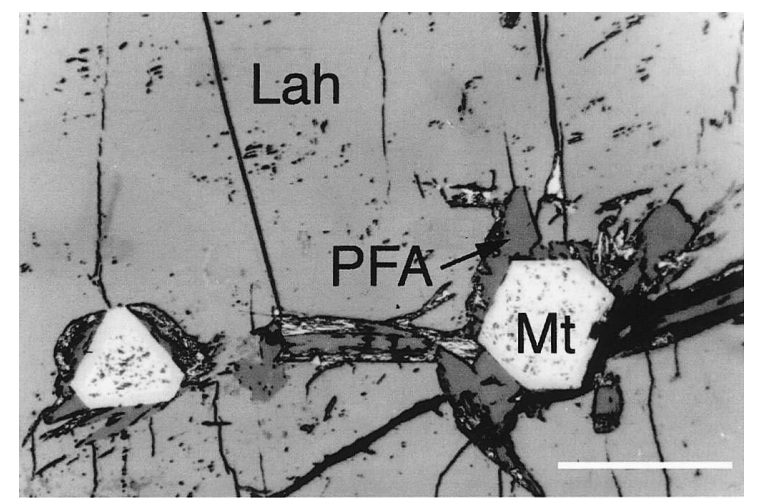

Figure 2 Photomicrograph of fayalite masses in granitic pegmatite from Hirukawa-mura, Gifu Prefecture, Japan (reflected light). Protoferro-anthophyllite (PFA) occurs in laihunite (Fe-deficient fayalite; Lah) and associated with magnetite (Mt). Scale bar is 100 $\mu \mathrm{m}$. 


\section{Protomangano-ferro-anthophyllite}

\section{Suisho-yama specimens}

The Suisho-yama specimens were collected from a massive fayalite block in the Suisyo-yama pegmatite, Iisaka (Iizaka), Kawamata Town, Fukushima Prefecture, Japan. The Suisho-yama area is underlain by the Abukuma granitic rocks, in which many granitic pegmatites are intruded (Watanabe et al., 1955). The Suisho-yama pegmatite was mined commercially for feldspar and quartz, and contains mainly biotite, almandine, fayalite, zircon, xenotime, allanite, fergu-sonite, uraninite, yttrialite-(Y), britholite-(Y), thoro-gummite, autunite, pyrite and molybdenite (e.g., Omori and Hasegawa, 1950, 1953; Nagashima and Nagashima, 1960). The fayalite block was found in the feldspar zone of the pegmatite along with biotite, almandine, and magnetite, and contained up to $20 \mathrm{wt} . \%$ $\mathrm{MnO}$ (Omori and Hasegawa, 1950).

The Suisho-yama specimens are dark brown massive blocks around $5-10 \mathrm{~cm}$ in diameter, and consist mostly of Mn-rich fayalite (12 wt\% $\mathrm{MnO}$ ) with a small amount of magnetite and quartz. PMFA occurs in the fayalite as brownish yellow fibrous crystals a few $\mathrm{mm}$ long and is associated with laihunite, magnetite, and quartz. It has often grown on the rim of magnetite. The protoamphiboles show almost parallel extinction, but they are often intergrown with clinoamphiboles with oblique extinction $\left(\gamma \wedge c=\sim 15^{\circ}\right)$. Twinned crystals of the protoamphibole were also observed in single-crystal precession photographs. The empirical formula is $\left(\begin{array}{lllllll}\mathrm{Mn}_{1.18} & \mathrm{Fe}_{0.74} & \mathrm{Mg}_{0.06} & \mathrm{Fe}_{5} & \mathrm{Si}_{8} & \mathrm{O}_{22} & (\mathrm{OH})_{2} \text {. The }\end{array}\right.$ Suisho-yama specimens are deposited at the University Museum collection of the University of Tokyo (Registration Nos. 25132, 25133, and 25134).

\section{Yokone-yama specimens}

The Yokone-yama specimens were collected from metamorphosed bedded-manganese deposits at Yokone-yama (Mt. Yokone), Awano Town, Tochigi Prefecture, Japan. Yokone-yama is located in the Ashio Mountains and is underlain by Paleozoic and Mesozoic sedimentary rocks. The sedimentary rocks underwent strong contact metamorphism of pyroxene-hornfels grade at the time of the Kobugahara granite intrusion, and the manganese deposits are also highly metamorphosed and partly metasomatized (Watanabe et al., 1970). The manganese ore is composed mainly of coarse-grained pyroxmangite, rhodonite, spessartine, manganese-bearing amphibole (now PMFA), rhodo-chrosite, and pyrrhotite (Watanabe et al., 1970).

The specimens are brownish-green and brownish -pink massive blocks up to $40 \mathrm{~cm}$ in diameter. The massive blocks consist of coarse-grained pyroxmangite, rhodonite, spessartine, rhodochrosite, pyrrhotite, trace pyrophanite, chalcopyrite, and galena. PMFA is present as light brownish yellow acicular crystals up to $15 \mathrm{~mm}$ in length and forms an aggregate resembling a wheat sheaf. The protoamphibole is associated with pyro-xmangite, rhodonite, spessartine, and rhodochrosite under the microscope (Fig. 3). Some of the proto-amphiboles are macroscopically transparent, colorless, and prismatic, a few $\mathrm{mm}$ in length. Clinoamphiboles with oblique extinction $\left(\gamma \wedge \mathrm{c}=\sim 15^{\circ}\right)$ are also present.

The PMFA is almost a single phase without intergrowths of clinoamphibole, but an intergrowth with another orthoamphibole (space group Pnma) is infrequently observed in single-crystal precession photographs. High-temperature $\mathrm{X}$-ray analyses have shown that the Pnma phase disappears at $800 \mathrm{C}(14 \mathrm{~h})$ (Matsuura, 1984). The empirical formula of the PMFA is $\left(\mathrm{Mn}_{1.38} \mathrm{Fe}_{0.59}\right)\left(\mathrm{Fe}_{4.1} \mathrm{Mg}_{0.9} \mathrm{Ca}_{0.03}\right) \mathrm{Si}_{8} \mathrm{O}_{22}(\mathrm{OH})_{2}$. The Yokone-yama specimens are deposited at the University Museum collection of the University of Tokyo (Registration Nos. 25129 and 25135).

\section{Physical and optical properties}

PFA from Hirukawa-mura has vitreous luster and is transparent with a pale brownish yellow tint under the microscope. The streak is white. Cleavage is perfect on (210). PMFA from Yokone-yama has vitreous luster and is transparent with a pale brownish yellow tint under the microscope. The hardness is 5-6 on the Mohs scale, and the streak is white. Cleavage is perfect on (210).

The optical properties of both protoamphiboles were reported by Sueno et al. (1998), but they gave an

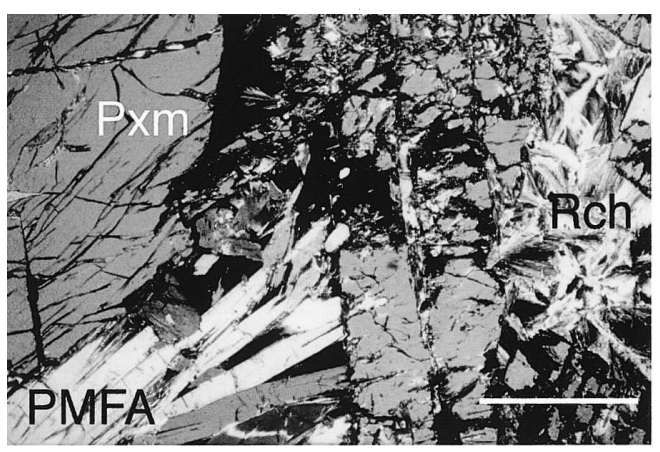

Figure 3. Photomicrograph of protomangano-ferro-anthophyllite in manganese ore deposit from Yokone-yama, Tochigi Prefecture, Japan (cross-polarized light). Protomangano-ferro-anthophyllite (Pmf) is acicular and associated with pyroxmangite (Pxm) and rhodochrosite (Rch). Scale bar is $200 \mu \mathrm{m}$. 
incorrect locality in their table. Thus, we present the correct information in Table 2. Both minerals are optically biaxial negative and show parallel extinction. The refractive indices of these protoamphiboles are almost identical to those of grunerite (Deer et al., 1997). Thus careful measurements of the extinction angle are important to distinguish between protoamphibole and grunerite $\left(\gamma \wedge \mathrm{c}=10^{\circ}\right)$ under the microscope. Manganogrunerite $\quad\left(\left(\mathrm{Mn}_{1.90} \mathrm{Ca}_{0.10}\right)\left(\mathrm{Fe}_{3.36} \mathrm{Mg}_{1.35} \mathrm{Mn}_{0.35}\right)\right.$ $\mathrm{Si}_{7.46} \mathrm{O}_{22}(\mathrm{OH})_{2}$ ) with parallel extinction has been reported from manganese deposits of the Renge Mine, Yamaguchi Prefecture, Japan (Yoshimura and Shirozu, 1947), and it is highly probable that this also was a PMFA.

\section{Powder diffraction data}

Cell parameters for the present natural and synthetic protoamphiboles, ferro-anthophyllite, and grunerite are shown in Table 3. The synthetic protoamphibole (Gibbs et al., 1960) is referred as protofluorian-lithian-anthophyllite. Cell dimensions of the present natural protoamphiboles are in close agreement with those reported for the synthetic protoamphiboles (Gibbs et al., 1960). Both protoamphiboles have an $a$-axis cell length equal to one-half that of ferro-anthophyllite with the same composition $\left(\mathrm{Fe}_{98} \mathrm{Mg}_{2}\right)$, because of the (+-) stacking sequence of the octahedra (Fig. 1). The $a$ - and $c$-axis cell lengths of PFA are almost identical to those of grunerite with the same composition $\left(\mathrm{Fe}_{98} \mathrm{Mg}_{2}\right)$, but the $b$-axis cell length is slightly shorter than that of the grunerite. PMFA exhibits longer $a$ - and shorter $b$-axis cell lengths than those of PFA because of the incorporation of $\mathrm{Mn}$.

X-ray powder diffraction data obtained with a Gandolfi camera and diffractometer for the natural protoamphiboles are shown in Table 4. The diffraction Table 2. Optic al properties of proto-am phiboles

\begin{tabular}{lll}
\hline \multicolumn{2}{c}{ Protofer ro-anthophyllite } & $\begin{array}{l}\text { Protomanga no-ferro- } \\
\text { anthophyllite } \\
\text { (Yokone-yama specimen) }\end{array}$ \\
\hline$\alpha *$ & 1.690 & 1.695 \\
$\beta$ & 1.710 & 1.714 \\
$\gamma$ & 1.726 & 1.731 \\
$\gamma-\alpha$ & 0.036 & 0.036 \\
$2 \mathrm{~V}$ & $86-88 \mathrm{P}$ & $76 \mathrm{P}$ \\
Orientat ion & $\mathrm{X}=\mathrm{a}, \mathrm{Y}=\mathrm{b}, \mathrm{Z}=\mathrm{c}$ & $\mathrm{X}=\mathrm{a}, \mathrm{Y}=\mathrm{b}, \mathrm{Z}=\mathrm{c}$ \\
Pleochrois m & weak & weak \\
& $\mathrm{X}, \mathrm{Y}, \mathrm{Z}=$ pale yell ow & $\mathrm{X}, \mathrm{Y}, \mathrm{Z}=$ pale \\
yell ow & & \\
\hline
\end{tabular}

* Refraction dat a measured by the dispersion mathod $(\lambda=589 \mathrm{~nm})$ (Matsuura, 1984).

data for anthophyllite and grunerite in Table 4 are taken from International Centre for Diffraction Data (ICDD) cards $9-455$ and $17-725$, respectively. Anthophyllite diffraction peaks with $d$-spacings less than $2.540 \AA$ were indexed on the basis of the data of Johansson (1930).

In contrast to the diffraction data for anthophyllite, the present protoamphiboles show no peak where $h=2 \mathrm{n}$ +1 in anthophyllite because the $a$-cell length is one-half that of anthophyllite (Table 4).

The protoamphiboles also show no peaks for $(0 k l)$ where $k+l=2 \mathrm{n}+1$ or $(h k 0)$ where $h+k=2 \mathrm{n}+1$ where $k+l=2 \mathrm{n}+1$ or $(h k 0)$ where $h+k=2 \mathrm{n}+1$ because of the Pnmn space group restriction. The three strongest peaks of anthophyllite and PFA are also different (Table 4). The most distinctive difference between the two powder patterns is the much greater complexity of that of anthophyllite. The anthophyllite pattern exhibits many peaks with intermediate intensities after the strongest peak $(d=3.05 \AA)$ until $d=$ $2.5 \AA$. Only three peaks of intermediate intensity are

Table 3. Unit cell dimensions of protoferro-anthophyllite and protomangano-ferro-anthophyllite

\begin{tabular}{|c|c|c|c|c|c|c|c|c|}
\hline \multirow[t]{2}{*}{$\begin{array}{l}\text { Cell } \\
\text { dimensions }\end{array}$} & \multicolumn{3}{|c|}{ Protoferro-anthophyllite*1 } & \multicolumn{2}{|c|}{$\begin{array}{l}\text { Protomangano-ferro- } \\
\text { anthophyllite }{ }^{* 1}\end{array}$} & \multirow{2}{*}{$\begin{array}{l}\text { Protofluorian } \\
\text {-lithian } \\
\text {-anthophyllite } \\
\text { (synthetic) }{ }^{* 3}\end{array}$} & \multirow{2}{*}{$\begin{array}{c}\text { Ferro- } \\
\text { anthophyllite } \\
\left(\mathrm{Fe}_{98} \mathrm{Mg}_{2}\right)^{* 4}\end{array}$} & \multirow{2}{*}{$\begin{array}{l}\text { Grunerite } \\
\left(\mathrm{Fe}_{98} \mathrm{Mg}_{2}\right)^{* 5}\end{array}$} \\
\hline & $\begin{array}{l}\text { Hirukawa } \\
\text {-mura*1 }\end{array}$ & $\begin{array}{l}\text { Cheyenne } \\
\text { Canyon*1 }\end{array}$ & $\begin{array}{l}\text { Cheyenne } \\
\text { Mountain*2 }\end{array}$ & $\begin{array}{l}\text { Yokone } \\
\text {-yama*1 }\end{array}$ & $\begin{array}{l}\text { Suisho } \\
\text {-yama*2 }\end{array}$ & & & \\
\hline $\mathrm{a}(\AA)$ & $9.388(2)$ & $9.382(2)$ & 9.41 & $9.425(2)$ & 9.40 & 9.330 & 18.578 & $9.383^{* 6}$ \\
\hline $\mathrm{b}(\AA)$ & $18.387(4)$ & $18.390(4)$ & 18.39 & $18.303(4)$ & - & 17.879 & 17.947 & 18.443 \\
\hline$c(\AA ̊)$ & $5.347(1)$ & $5.343(1)$ & 5.35 & $5.345(1)$ & 5.35 & 5.288 & 5.286 & 5.343 \\
\hline $\mathrm{V}_{\text {calc }}\left(\AA^{3}\right)$ & $923.0(3)$ & $921.9(7)$ & 925 & $922.0(3)$ & - & 882.1 & 1761.6 & 924.6 \\
\hline & & 2 & 2 & 2 & - & 2 & 4 & 2 \\
\hline$\overline{\mathrm{D}}_{\text {calc }}\left(\mathrm{g} / \mathrm{cm}^{3}\right)$ & 3.54 & 3.55 & - & 3.44 & 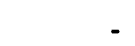 & 2.928 & & 3.57 \\
\hline Space group & p Pnmn & Pnmn & Pnmn & Pnmn & Pnmn & Pnmn & Pnma & $\mathrm{C} 2 / \mathrm{m}$ \\
\hline
\end{tabular}

${ }^{* 1}$ Measured with 4-circle automatic diffractometer. ${ }^{* 2}$ Measured from single-crystal precession photographs because of presence of the clinoamphibole lamellae in the crystals (Sueno et al., 1998). ${ }^{* 3}$ Gibbs et al. (1960). ${ }^{* 4}$ Calculated with formula from Popp et al. (1976). ${ }^{* 5}$ Calculated with formula from Klein (1964). $\quad{ }^{* 6}$ Calculated from a $\sin \beta$. 
Table 4. X-ray powder diffraction data for the protoamphiboles, anthophyllite, and grunerite

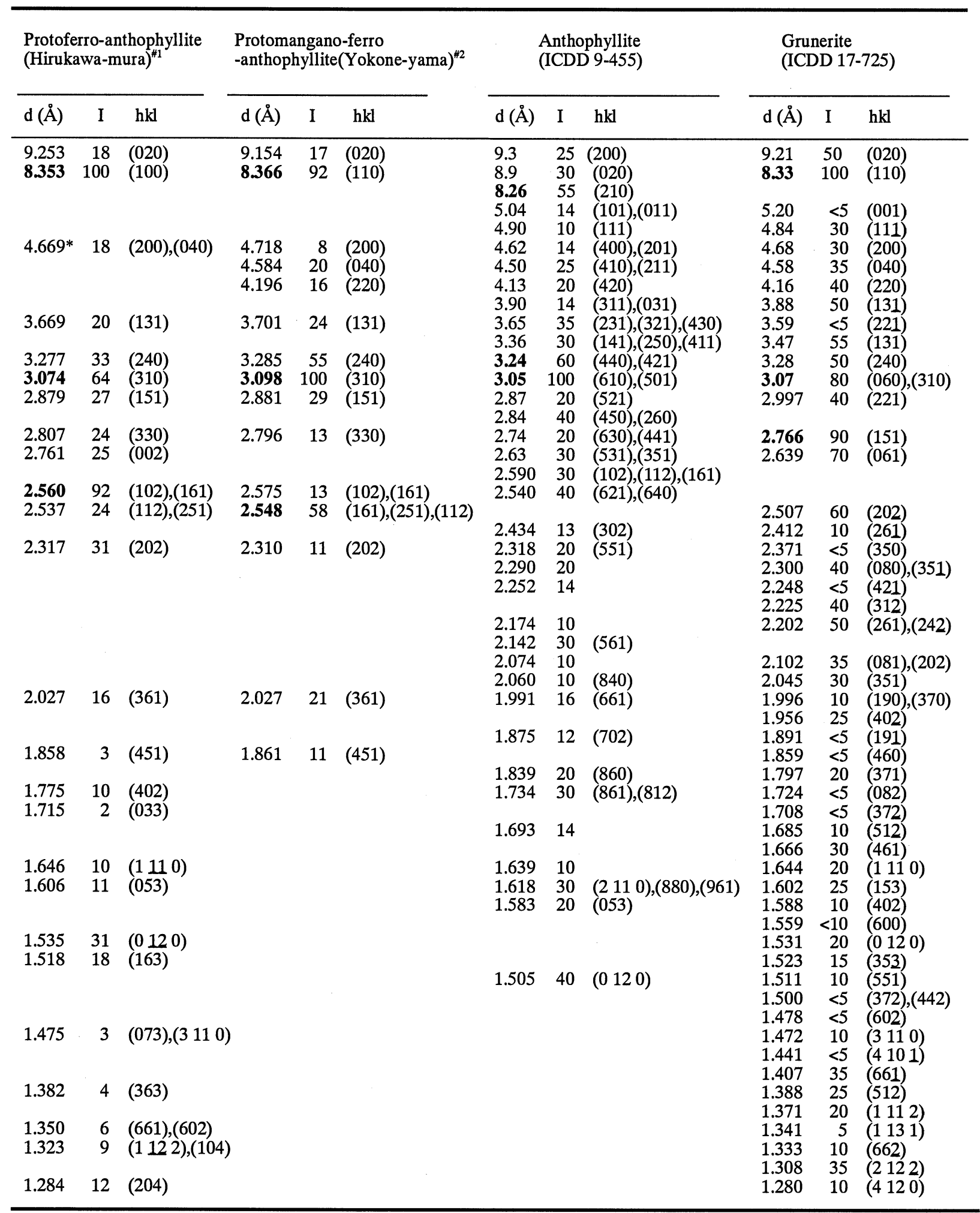

The three strongest peaks of each mineral are in bold face. " ${ }^{11}$ Hirukawa-mura specimen: measured with a Gandolfi camera and micro-densitometer

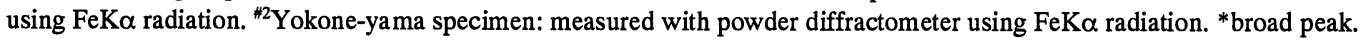


present between the two strong peaks $(d=3.074$ and $2.560 \AA$ ), and only one between $d=2.5 \AA$ and $2.0 \AA$, in PFA. The powder pattern of PMFA shows the same tendency as that of PFA. The distinctive differences between the powder patterns of grunerite and these protoamphiboles are the strongest peak at $d=2.766 \AA$ and the much greater complexity of the grunerite pattern.

\section{Structural features of natural protoamphiboles}

A complete refinement of the crystal structure of the natural protoamphiboles was performed by using $\mathrm{X}$-ray intensity data from a 4-circle automatic diffractometer (MoK $\alpha$ radiation and graphite monochrometer) to reveal the structural features of the protoamphiboles (Matsuura, 1984). Because there was no intergrowth with clinoamphibole, protoamphibole crystals from Hirukawa-mura $\left(35 \times 65 \times 115 \mu^{3}\right.$ size $)$ and Yokone-yama $\left(50 \times 100 \times 200 \mu^{3}\right.$ size $)$ were used as the samples for PFA and PMFA, respectively. The X-ray intensity data were corrected for $L p$-effects but not for absorption effects. Mn was assumed to occupy the M(4) site. 1493 and 1520 intensity data were used for the least-square refinements (Finger and Prince, 1975), and the final R-factors were 0.035 and 0.050 for PFA and PMFA, respectively.

The positional parameters, equivalent isotropic temperature factors, site occupancies, and selected inter-atomic distances and angles were already shown by Sueno et al. (1998). In addition, they reported a brief description of the structure and discussed the co-ordination number of the $\mathrm{M}(4)$ cation and a distortion of the tetrahedra. Thus, we summarize here two important structural features of the natural protoamphiboles: the straight double chain and the shortening of the $b$-axis by Mn incorporation (Matsuura, 1984; Sueno and Matsuura, 1986; Sueno et al., 1997; Sueno et al., 1998).

The tetrahedral chain angles $(\mathrm{O}(5)-\mathrm{O}(6)-\mathrm{O}(5)$ angle) of the PFA and PMFA were close to 180 (Table 5 and Fig. 4). In the extended tetrahedral chain model for amphiboles, the ideal geometrical relation without distortion of the polyhedra is found when the following condition is met (Hawthorne, 1983).

$$
[\mathrm{M}-\mathrm{O} \text { distance }]=4 / 3 \cdot[\mathrm{T}-\mathrm{O} \text { distance }] \cdot \sin (\theta / 2)
$$

where $\theta$ is the tetrahedral chain angle. The natural protoamphiboles show little deviation from the above relation and are very close to an extended tetrahedral chain structure. The small deviation from this model
Table 5. Selected interatomic distances and angles, and site occupancies for natural and synthetic protoamphiboles and grunerite

$\begin{array}{lll}\text { Protoferro } & \text { Protomangano Grunerite*1 } & \text { Protofluorian } \\ \text {-anthophyllite } & \text {-ferro-anthophyllite } & \text {-lithian } \\ \text { (Hirukawa-mura) } & \text { (Yokone-yama) } & \text {-anthophyllite*2 }\end{array}$

\begin{tabular}{|c|c|c|c|c|}
\hline \multicolumn{5}{|c|}{ Interatomic distance $(\AA)$} \\
\hline Mean Si(1)-O & 1.620 & 1.619 & 1.627 & 1.614 \\
\hline Mean $\mathrm{Si}(2)-\mathrm{O}$ & 1.627 & 1.627 & 1.622 & 1.620 \\
\hline Mean M(1)-O & 2.126 & 2.121 & 2.121 & 2.070 \\
\hline Mean M(2)-O & 2.132 & 2.122 & 2.121 & 2.084 \\
\hline Mean M(3)-O & 2.114 & 2.113 & 2.113 & 2.048 \\
\hline Mean M(4)-O & 2.264 & 2.256 & 2.293 & 2.196 \\
\hline $\mathrm{M}(4)-\mathrm{O}(2)$ & 2.141 & 2.155 & 2.135 & 2.107 \\
\hline $\mathrm{M}(4)-\mathrm{O}(4)$ & 1.980 & 2.032 & 1.988 & 2.029 \\
\hline $\mathrm{M}(4)-\mathrm{O}(6)$ & 2.671 & 2.582 & 2.757 & 2.453 \\
\hline Mean M-O & 2.159 & 2.153 & 2.162 & 2.100 \\
\hline \multicolumn{5}{|c|}{ Interatomic angle } \\
\hline \multicolumn{2}{|c|}{$\mathrm{O}(5)-\mathrm{O}(6)-\mathrm{O}(5) \quad 177.2 \mathrm{P}$} & $178.6 \mathrm{P}$ & $172.7 p$ & $172.5 \mathrm{P}$ \\
\hline \multicolumn{5}{|l|}{ Site occupancy } \\
\hline $\mathrm{M}(1)$ & $\left(\mathrm{Fe}_{1.0}\right)$ & $\left(\mathrm{Fe}_{0.88} \mathrm{Mg}_{0.12}\right)$ & $\left(\mathrm{Fe}_{0.858} \mathrm{Mg}_{0.152}\right)$ & $\left(\mathrm{Mg}_{1.0}\right)$ \\
\hline $\mathrm{M}(2)$ & $\left(\mathrm{Fe}_{0} \mathrm{Mg}_{0 \Omega}\right)$ & $\left(\mathrm{Fe}_{0.752} \mathrm{Mg}_{0.248}\right)$ & $\left(\mathrm{Fe}_{0.773} \mathrm{Mg}_{0.227}\right)$ & $\left(\mathrm{Mg}_{1.0}\right)$ \\
\hline $\mathrm{M}(3)$ & $\left(\mathrm{Fe}_{10}\right)$ & $\left(\mathrm{Fe}_{0.835} \mathrm{Mg}_{0.165}\right)$ & $\left(\mathrm{Fe}_{0.888} \mathrm{Mg}_{0.112}\right)$ & $\left(\mathrm{Mg}_{1.0}\right)$ \\
\hline $\mathrm{M}(4)$ & $\left(\mathrm{Fe}_{0.80} \mathrm{Mn}_{0.20}\right)$ & $\left(\mathrm{Mn}_{0.700} \mathrm{Fe}_{0.300}\right)$ & $\left(\mathrm{Fe}_{0.985} \mathrm{Mg}_{0.015}\right)$ & $\left(\mathrm{Mg}_{0.75} \mathrm{Li}_{0.25}\right)$ \\
\hline
\end{tabular}

${ }^{* 1}$ Finger (1969). $\quad{ }^{* 2}$ Synthetic sample (Gibbs, 1969).

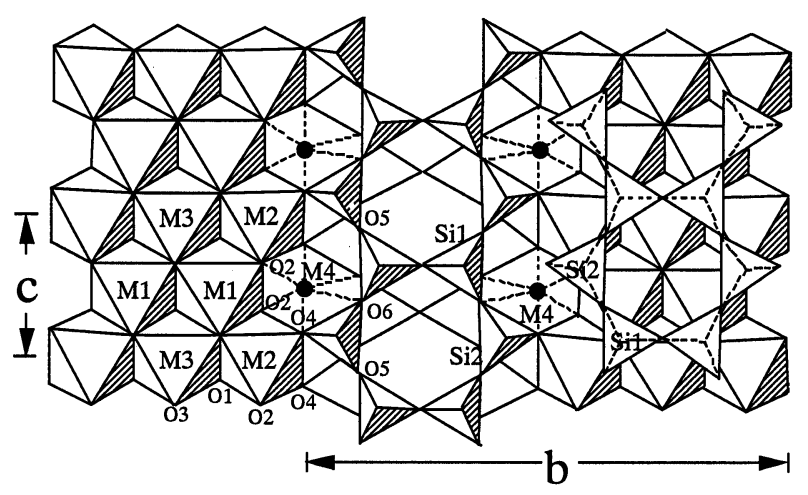

Figure 4. Crystal structure of protoferro-anthophyllite from Hirukawa-mura, viewed along the $a$-axis.

means that there are only very small distortions of the octahedra.

Table 6 shows the degree of distortion for the polyhedra calculated on the basis of deviations of individual interatomic distances and angles from the mean (Hawthorne, 1983). The distortions of the M(1) and $\mathrm{M}(3)$ octahedra of the natural protoamphiboles are smaller than those of grunerite, showing almost regular shapes (Table 6). Although the distortions of the M(2) octahedra are slightly larger than those of grunerite, the large distortions observed in the synthetic protoamp-hibole (protofluorian-lithian-anthophyllite) 
are absent. The very small distortions of the octahedra and the linear arrangement of the double chain are due to the occupation of the $M(1), M(2)$, and $M(3)$ sites by the relatively large $\mathrm{Fe}$ ion (Table 5). When the $\mathrm{T}(\mathrm{Si})-\mathrm{O}$ interatomic distance in the amphibole structure is 1.62 $\AA$, a cation $0.78 \AA$ in size in the octahedral site is required for the linear arrangement to exist without distortion and misfit between polyhedra (Hawthorne, 1979). The present natural protoamphiboles have the same mean ionic radius of $0.782 \AA$ for the M-site, so the linear arrangement without polyhedral distortions is attained. Although PMFA contains a large amount of $\mathrm{Mn}$, the mean ionic radius is balanced by the relatively high occupancy by the small $\mathrm{Mg}$ ion. Judging from the straight tetrahedral chain observed in protoenstatite (Smith, 1959), the straight double chain with high occupancy by $\mathrm{Fe}$ in the $\mathrm{M}(1)-\mathrm{M}(3)$ sites could be related to the stabilization of the protoamphibole structure.

In the natural protoamphiboles, the $\mathrm{Mn}$ ion, which is larger than the $\mathrm{Fe}$ ion, occupies the $\mathrm{M}(4)$ site. The mean $\mathrm{M}(4)-\mathrm{O}$ distance, however, is shorter than that of

Table 6. Polyhedron distortion parameters in the protoamphiboles and grunerite

\begin{tabular}{cccccccccc}
\hline $\mathrm{T}(1)$ & $\mathrm{T}(2)$ & & $\mathrm{M}(1)$ & & $\mathrm{M}(2)$ & $\mathrm{M}(3)$ \\
\cline { 5 - 7 } & $\Delta^{* 1} \sigma^{2}$ & $\Delta$ & $\sigma^{2}$ & $\Delta$ & $\sigma^{2}$ & $\Delta$ & $\sigma^{2}$ & $\Delta$ & $\sigma^{2}$ \\
\hline
\end{tabular}

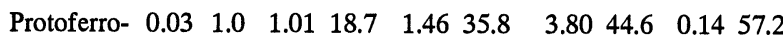
anthophyllite

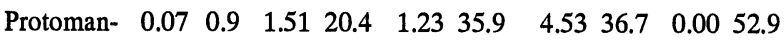
gano-ferro-

anthophyllite

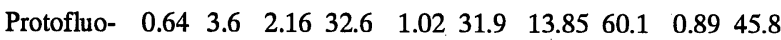
rian-lithian-

anthophyllit $e^{* 2}$

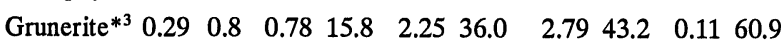

${ }^{* 1} \Delta$ and $\sigma^{2}$ values were calculated with data from Sueno et al. (1998) and the following formulas (Hawthorne, 1983);

$\Delta=\left\{{ }_{i=1}^{n}\left[\left(I_{1}-I_{m}\right) / I_{m}\right]^{2} / n\right\} \times 10^{4}$

where $l_{1}=$ individual bond length, $l_{m}=$ mean bond length, $\mathrm{n}=$ number of bonds in coordination polyhedron;

$\sigma^{2}={ }_{i=1}^{n}\left(\theta_{i}-\theta_{m}\right)^{2} /(n-1)$

where $\theta_{\mathrm{i}}=$ individual bond angle, $\theta_{\mathrm{m}}=$ ideal bond angle, $\mathrm{n}=$ number of bond angles in coordination polyhedron.

*2 Calculated with data from Gibbs (1969). $\quad{ }^{* 3}$ Calculated with data from Finger (1969). grunerite (Table 5). In addition, the mean $\mathrm{M}(4)-\mathrm{O}$ distance of PMFA is shorter than that of PFA, despite the higher occupancy of the larger $\mathrm{Mn}$ ion in the M(4) site of the former (Table 5). The shorter mean M(4)-O distance of PMFA is ascribed to shrinkage of the $\mathrm{M}(4)-\mathrm{O}(6)$ distance, although the $\mathrm{M}(4)-\mathrm{O}(2)$ and $\mathrm{M}(4)-\mathrm{O}(4)$ distances are longer than those of PFA and grunerite. The extension of the $\mathrm{M}(4)-\mathrm{O}(2)$ and $\mathrm{M}(4)-\mathrm{O}(4)$ distances and the shrinkage of the $\mathrm{M}(4)-\mathrm{O}(6)$ distance bring about the elongation of the $a$ and $c$ cell edges and the shortening of the $b$-axis (Fig. 4). A shortening of the $b$-axis by $\mathrm{Mn}$ incorporation is also observed in a comparison of the cell parameters between manga-nocummingtonite (Jaffe et al., 1961) and cummingtonite (Ghose, 1961). Since the $b$ cell edge of protoenstatite is much shorter than that of enstatite (Smith, 1969), the observed shortening of the $b$-axis by $\mathrm{Mn}$ incorporation may also contribute to the stabilization of the proto-type structure.

\section{Natural occurrence of protoamphiboles}

The present protoamphiboles mostly coexisted with magnetite and laihunite in the fayalite masses. Since the occurrence of laihunite and magnetite indicate a genesis by an oxidization reaction of fayalite (Sueno et al., 1985), an oxidation reaction and/or retrograde alter-ations could also be related to the formation of natural protoamphiboles. The occurrence at Yokone-yama also indicates a genetic relation to metasomatism in manga-nese ore deposits. Hydrothermal alteration at relativ-ely low temperature may play a role in giving rise to the protoamphibole structure. The present protoamphiboles mostly coexisted with clinoamphiboles and/or included lamellae of a clinoamphibole (grunerite) and another orthoamphibole (Pnma), so the stability fields of the protoamphiboles must be determined to understand their formation and occurrence.

The chemical compositions of the natural and synthetic protoamphiboles almost correspond to those of the Fe- and Mg-end members, respectively, of the $\mathrm{Mg}-\mathrm{Fe}$ protoamphiboles. This indicates the possible occur-rence of new protoamphiboles from $\mathrm{Fe}$ - or Mg-rich chemical environments. Further studies of the relation-ship between chemical composition and stabilization of the protoamphibole structure are also important for finding new proto-type biopyriboles.

\section{Summary}


We reported the occurrence, physical properties, and crystal chemical features of two new orthoamphiboles with proto-type structure. PFA was found in fayalite-laihunite-magnetite-quartz massive aggregate from granitic pegmatites in the Cheyenne Canyon and Cheyenne Mountain area, U.S.A., and at Hirukawa-mura, Japan. PMFA was found in a Mn-rich fayalite or laihunite massive block from granitic pegmatite at Suisho-yama, Japan, and also in the metamorphosed bedded-manganese ore deposit at Yokone-yama, Japan. The two protoamphiboles were isostructural with synthetic protofluorian-lithian-anthophyllite (space group Pnmn) and had a straight double tetrahedral chain and $\mathrm{M}(1)-\mathrm{M}(3)$ octahedra of regular shape. Judging from the structure of protoenstatite, the straight double chain by occupation of $\mathrm{Fe}$ in the $\mathrm{M}(1)-\mathrm{M}(3)$ sites could promote the stabilization of the protoamphibole structure. The shortening of the $b$-axis by $\mathrm{Mn}$ incorporation into the $\mathrm{M}(4)$ site may also contribute to the stabilization.

The two protoamphiboles were chemically and optically similar to grunerite. The extinction angle and the X-ray powder diffraction pattern, however, differed significantly from those of grunerite, so that a distinction among these minerals is possible. Some of the protoamphiboles coexsited with clinoamphibole (grunerite) and/or included lamellae of a clinoamphibole and another orthoamphibole (Pnma). Judging from the mineral assemblages and occurrences, the present protoamphiboles seem to have formed by hydrothermal alteration at relatively low temperature and/or metasomatism. Determination of the stability field of the protoamphiboles is important further work for understanding the occurrence of proto-type biopyriboles.

\section{Acknowledgments}

The authors wish to thank Mr. Y. Suzuki (Hitachi City) and Dr. H. Hori (Hori Mineralogy Ltd.) for providing the Hirukawa-mura and Suisho-yama specimens. We also wish to thank Dr. Y. Suzuki, Dr. T. Miyano, Dr. M. Kimata, Mr. N. Nishida (University of Tsukuba), Mr. K. Kakefuda (Rigaku Co. Ltd.), Dr. I. Nakai (Science University of Tokyo), Dr. H. Yurimoto (Tokyo Institute of Technology), Dr. G. V. Gibbs and Dr. M. B. Boisen (Virginia Polytechnic Institute) for their assistance of optical, chemical, X-ray measurements and the useful discussions. One of the authors (S. S.) would like to express the thanks to Dr. C. T. Prewitt (Geophysical Laboratory) and Dr. J. J. Papike (University of New
Mexico) for guidance in the crystal chemical study of pyroxenes and amphiboles at the State University of New York. The manuscript benefited from comments by Dr. S. Matsubara (National Science Museum) and Dr. Y. Bannno (Geological Survey of Japan) and handling by Dr. R. Miyawaki (National Science Museum).

\section{References}

Barker, F., Wones, D.R., Sharp, W.N. and Desborough, G.A. (1975) The Pikes Peak batholith, Colorado Front Range, a model for the origin of the gabbro-anorthosite-syenite-potassic granite. Precambrian Research, 2, 97-160.

Deer, W.A., Howie, R.A. and Zussman, J. (1997) Rock-Forming Minerals, 2B, Double-Chain Silicates. Second edition. pp. 764, The Geological Society, London.

Finger, L.W. (1969) The crystal structure and cation distribution of a grunerite. Mineralogical Society of America, Special Paper, 2, 95-100.

Finger, L.W. and Prince, E. (1975) A system of FORTRANIV computer programs for crystal structure computations. National Bureau of Standards and Technology Note, 854.

Ghose, S. (1961) The crystal structure of a cummingtonite. Acta Crystallographica, 14, 622-627.

Gibbs, G.V. (1969) Crystal structure ofprotoamphibole. Mineralogical Society of America, Special Paper, 2, 101-109.

Gibbs, G.V., Bloss, F.D. and Shell, H.R. (1960) Protoamphibole, a new polytype. American Mineralogist, 45, 974-989.

Hawthorne, F.C. (1979) The crystal chemistry of the amphiboles. X. Refinement of the crystal structure of ferroglaucophane and an ideal polyhedral model for clinoamphiboles. Canadian Mineralogist, 17, 1-10.

Hawthorne, F. C. (1981) Crystal chemistry of the amphiboles. In Reviews in Mineralogy, 9A, Amphiboles and Other Hydrous Pyriboles-Mineralogy (Veblen, D.R., Ed.). pp.372, Mineralogical Society of America, Washington D. C., 1-66.

Hawthorne, F.C. (1983) The crystal chemistry of the amphiboles. Canadian Mineralogist, 21, 173-480.

Jaffe, H.W., Groeneveld Meijer, W.O.J. and Selchow, D.H. (1961) Manganoan cummingtonite from Nsuta, Ghana. American Mineralogist, 46, 642-653.

Johansson, K. (1930) Vergleichende Untersuchungen an Anthophyllit, Grammatit und Cummintonit. Zeitschrift für Kristallographie, 73, 31-51.

Klein, C. (1964) Cummingtonite-grunerite series: a chemical, optical and X-ray study. American Mineralogist, 49, 963-982.

Matsuura, S. (1984) Crystal chemical study of space group Pnmn-type $\mathrm{Fe}, \mathrm{Mn}$ amphiboles. Masters thesis, University of Tsukuba (in Japanese).

Matsuura, S. and Sueno, S. (1984) The crystal structure of iron amphibole with the space group Pnmn. Mineralogical Society of Japan 1984 Annual Meeting Abstract, p.128 (in Japanese).

Matsuura, S., Sueno, S. and Bunno, M. (1985) The crystal chemistry of $\mathrm{Fe}-\mathrm{Mn}$ amphiboles with proto-type structure. Mineralogical Society of Japan 1985 Annual Meeting Abstract, p. 63 (in Japanese).

Nagashima, O. and Nagashima, K. (1960) Rare Element Minerals from Japan. Working Group commemorating Mr. O. Nagashima, 463 pp. (in Japanese). 
Omori, K. and Hasegawa, S. (1950) Iron knebelite from a pegmatite in lizaka Village, Date County, Fukushima Prefecture. Journal of Mineralogy Petrology and Economic Geology, 34, 107-113 (in Japanese).

Omori, K. and Hasegawa, S. (1953) Yttrialite and abukumalite from a pegmatite of Suisho-yama, lizaka Village, Fukushima Prefecture. Journal of Mineralogy Petrology and Economic Geology, 37, 21-29 (in Japanese with English abstract).

Popp, R.K., Gilbert, M.C. and Craig, J.R. (1976) Synthesis and X-ray properties of Fe-Mg orthoamphiboles. American Mineralogist, 61, 1267-1279.

Shibata, H. (1939) Granitic rock and pegmatites at Naegi district, Ena County, Mino Province. Part II. Journal of Geological Society of Japan, 46, 503-518 (in Japanese).

Shibata, H. (1952) Mineralizations in granite-pegmatites in Japan and Korea. Part II. Science Reports of the Tokyo Bunrika Daigaku, Section C, 2, 107-144.

Smith, J.V. (1959) The crystal structure of proto-enstatite, $\mathrm{MgSiO}_{3}$. Acta Crystallographica, 12, 515-519.

Smith, J.V. (1969) Crystal structure and stability of the $\mathrm{MgSiO}_{3}$ polymorphs; physical properties and phase relations of $\mathrm{Mg}$, $\mathrm{Fe}$ pyroxenes. Mineralogical Society of America, Special Paper, 2, 3-29.

Sueno, S. and Matsuura, M. (1986) A study of two natural proto amphiboles. 14th International Mineralogical Association Meeting Abstracts, p241.
Sueno, S., Matsuura, S. and Gibbs, G.V. (1997) Occurrences and crystal chemistry of natural proto-Amphiboles. Abstract of American Geophysical Union 1997 Fall Meeting, V11A-02.

Sueno, S., Matsuura, S., Gibbs, G.V. and Boisen, Jr., M.B. (1998) A crystal chemical study of protoanthophyllite: orthoamphiboles with the protoamphibole structure. Physics and Chemistry of Minerals, 25, 366-377.

Sueno, S., Matsuura, S. and Prewitt, C.T. (1985) Fe-deficient olivine structure type minerals from Colorado, U. S. A. and Japan. Mineralogical Journal, 12, 376-392.

Watanabe, I., Gorai, M., Kuroda, Y., Ono, K. and Togawa, T. (1955) Igneous activities of the Abukuma plateau, part 9. Earth Science, 24, 1-11 (in Japanese).

Watanabe, T., Yui, S. and Kato, A. (1970) Bedded manganese deposits in Japan, a review. In Volcanism and Ore Genesis (T. Tatsumi ed.). pp448, University of Tokyo Press, Tokyo, 119-142.

Yoshimura, T. and Shirozu, H. (1947) A variety of dannemorite from Renge Mine, Yamaguchi Prefecture. Journal of Geological Society of Japan, 53, 58-59 (in Japanese).

Manuscript received; 26 February, 2002

Manuscript accepted; 27 May, 2002 